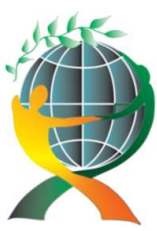

\author{
(online) $=$ ISSN $2285-3642$ \\ ISSN-L = $2285-3642$ \\ Journal of Economic Development, Environment and People \\ Volume 7, Issue 4, 2018
}

URL: http://jedep.spiruharet.ro

e-mail: office jedep@spiruharet.ro

\title{
Ethical Universities of Integrity and Ethics Management in the Romanian University Environment
}

\author{
Elena Gurgu, Rocsana Tonis (Bucea-Manea) \\ ${ }^{1}$ Spiru Haret University, Faculty of Economic Sciences \\ elenagurgu@yahoo.com, rocsanamanea.mk@spiruharet.ro
}

\begin{abstract}
The paper shows that, now, the University is an institution whose goals, valid for each of its members, include development and professional affirmation, the evolution of knowledge and research in the conditions of respect for the rule of law and human rights. The University respects the dignity of each of its members and promotes academic integrity on ethical principles. Its members are committed to contributing to the democratic development and prosperity of society. The values and principles that universities promote in particular, and whose actual achievement is sought to ensure, are: academic freedom, personal autonomy, justice and equity, merit, professionalism, honesty and intellectual integrity, transparency, respect and tolerance, responsibility, goodwill and care. The management of ethics in the academic environment is the coordination of all elements related to the moral life of a university. "Institutionalization of ethics" in academia is a new reality for which we must be prepared. I believe that, the last decades have insistently imposed on public awareness the importance of taking into account the ethical dimension of the life of universities. Ethical codes, ethics committees, ethical audits, ethical education of staff, techniques to create an institutional culture of a moral nature have all become increasingly widespread.
\end{abstract}

Keywords: ethics management, applied ethics, academic integrity, ethical training, the state of immorality in the academic environment

JEL Codes: 121,123

\section{Introduction in the historical background and evolution of ethics management in the university environment}

Concerns about improving morality are surprisingly old, and they have always been the mark of the civilized world. In modern times, there is the temptation to neglect such civic engagements and public programs of moral improvement. We still have the illusion that ethics can be reduced to spontaneous compliance with laws and regulations.

Philosophers of morality have always been interested in the usefulness and applicability of their theories. Studying the theories of some authors such as Kant, Mill, or Hare, any student was able to see the emphasis they put on "apps" - procedures first, viewed as exercises, to show that theory works. 


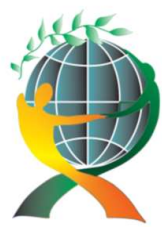

\author{
(online) $=$ ISSN $2285-3642$ \\ ISSN-L = $2285-3642$ \\ Journal of Economic Development, Environment and People \\ Volume 7, Issue 4, 2018 \\ URL: http://jedep.spiruharet.ro \\ e-mail: office jedep@spiruharet.ro
}

The etymology of the ethical word derives from the Greek ethos that originally defined the customs in general, but today it is reduced only to the meaning of moral customs. Ethos also mentions the moral profile of the human community, the morale of the groups.

The applied ethics deals with contextualization, problem solving of concrete situations, thus is providing accurate moral guidance. It deals with the study of controversial issues of contemporary society, in fields such as university ethics, pedagogical ethics, bioethics etc. Focused on the study of deviations from the traditional principles of morality, the applied ethics aims to broaden the thematic field of ethics and limit generality, thus providing answers about the concrete life of a person or a distinct community, such as the academic environment.

In recent years, the importance of taking into account the ethical dimension of academic life has been strongly imposed on public consciousness. Ethical codes, ethics committees, ethical audit, ethical education of staff, techniques to create an academic culture of moral nature have become more and more widespread. "Institutionalizing university ethics" is a new reality. The various "ethical content" in the academic world has begun to force new theoretical refinements, simply generating a new branch of management - the management of university ethics.

Management of ethics in the university environment as a management discipline deals with the development of those leadership tools that contribute to the ethical development of a university as well as those methods that can be used to determine the direction in which the academia should develop. The management of ethics in the university environment presupposes the description and analysis of the current ethical situation through "ethical audit", i.e. by assessing the state of "ethical content" of the academic environment, determining the desirable situation and deciding on the measures to be taken in perfect harmony with the other forms of management (e.g. "ethical development of the university"). Management of ethics in the university environment is the result of the increasingly visible imprinting of the academic environment with responsibility / morality, regarded as an indispensable condition of their existence. A university demonstrates moral responsibility when it subordinates its interests to the interests of its clients, the students.

In this context, ethics management in the university environment is represented by all the activities and measures that follow the institutional organization of ethics for the creation of integrated universities.

Not to confuse ethics management with ethics of management or management ethics, i.e. the study and control of ethical issues raised by different forms of management - strategic management, quality management, social management, etc.

The management of ethics in the university is altogether different. This represents a new branch of management of an educational institution. It must also be distinguished from "academic ethics" in the broad sense, that is, from the traditional analysis of ethical issues in universities to provide normative clarifications and moral guidance, using various ethical theories and analytical tools provided by the philosophy of morality.

Academic ethics is an area at the intersection between ethics of research, ethics management in the academic environment and the professional deontology of the researcher or professor. The concerns possibly circumscribed in this area are far from being a recent development (since the dawn of modernity, ethical debates about the correlative debts of teachers and students, or topics such as the moral 


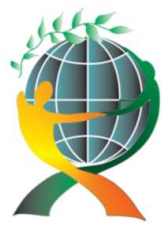

\author{
(online) $=$ ISSN $2285-3642$ \\ ISSN-L = $2285-3642$ \\ Journal of Economic Development, Environment and People \\ Volume 7, Issue 4, 2018 \\ URL: http://jedep.spiruharet.ro \\ e-mail: office jedep@spiruharet.ro
}

acceptability of the use of corpses for the development of medical knowledge). Although, there has been a significant autonomy in the last 20-25 years, especially as a result of the need to respond theoretically to requirements arising from research and education funding bodies as well as from public opinion. Thus, dedicated journals have appeared or consolidated (the most well known is probably the Journal of Academic Ethics, edited at Springer), and several books or compendia have been published.

According to Ronald Jeurissen's opinion, ethics management in the university environment aims to improve decision-making processes, procedures and academic structures, so that academic activities are as much as possible linked to ethical principles. The tools used are ethical codes, ethical audit, and other strategies to lead a university on the path of morality. According to Donald Menzel, ethics management in the academic environment does not consist of controlling and penalizing the behavior of academic staff or reflecting on the ethics of the academic workplace. It is rather the set of actions taken by deans or vicerectors to stimulate the formation of a moral conscience and an ethical sensitivity capable of impregnating all aspects of university activity. This type of ethics management in the university environment is to promote and maintain a strong ethical culture in the workplace in the academic environment.

The experience of ethics management in the world's universities is short-lived, about two to three decades, but some models of university ethics have been proposed. Some authors speak of four stages in the evolution of ethics management in the university environment, namely: the initial stage, ethical awareness, the stage of ethical reasoning, consisting of procedures and criteria for decision-making, the stage of ethical action and the stage of ethical leadership, promoting employment and ethical culture.

At this moment, in Romania, ethics in higher education is approached as "something to be done", being imposed by normative acts. Therefore, most Romanian universities aim at fulfilling the minimum standards imposed by specific methodologies, the effects of which are relatively low. Compliance with national standards leads to uniformity, compliance. However, we consider that a voluntary approach to ethics management in the higher education system is necessary in order to increase the competitiveness of the system. The elements of ethics management in the university environment must be acknowledged and assumed by each academic member of the academic environment.

University ethics management must offer the opportunity to exchange good practices and promote both traditional European values, such as solidarity, cooperation, freedom, tolerance, efficiency, respect for human rights and the principles of ethics management, and of total quality. All these are materialized in orientation towards students, the internalization of student-faculty/university relationship, the quality of primary education, continuous improvement of teaching methods, system vision and data argumentation.

The effectiveness of ethics management in the academic environment, generally speaking, depends on the university's ability to exploit all types of information, namely all communication channels, both formal and informal, thus building an open ethic culture university. This is fundamental in the university environment where the construction of an "ethical learning community" calls for the presence of efficient information networks - supported both by structural platforms and by individual efforts. 


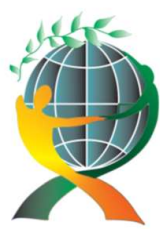

\author{
(online) $=$ ISSN $2285-3642$ \\ ISSN-L = $2285-3642$ \\ Journal of Economic Development, Environment and People \\ Volume 7, Issue 4, 2018 \\ URL: http://jedep.spiruharet.ro \\ e-mail: office jedep@spiruharet.ro
}

\title{
2. Ethics management in the Romanian academic environment
}

D. Menzel believes that, in order to build "ethical universities of integrity," we are forced to rely on ethics management in the university environment, which can acquire four types of strategic approach. The first is the compliance-based strategy, i.e. the formulation and enforcement of ethical rules in the academic environment. The second is the cost-inclusion strategy, a vision that treats unethical actions as a cost factor, which must be reduced, minimized or eliminated. The third is the learning strategy, where the emphasis is on ethical training processes and assimilation of ethical provisions. The fourth is the strategy of creating an academic culture of a moral nature. This is considered the most promising of all, assuming the others.

Interesting is also the list of "tools at the disposal of ethics managers in the academia", tools to help build ethical universities of integrity. These tools are a moral exemplary leadership team; ethical training in the university; the existence and implementation of ethical codes at the academic level; professional vows; ethical audit, human resources management (teachers) respecting ethical criteria at academic level; moral counselors.

Ethical training is considered the most important method of the above, and the means of enforcing morality (signing an oath, assessing performance, penalizing, etc.) have the least importance in determining staff to comply with ethical rules, contrary to the common viewpoint that the enforcement and sanctioning mechanisms are most effective. This conclusion confirms the idea of Kantian origin that ethical rules should not be imposed but self-imposed autonomously.

G. Rossouw and L. van Vuuren present an interesting evolutionary point of view, which starts from the finding by several experts that "universities are experiencing a process of evolution in order to increase their sophistication in terms of ethical performance management." The two authors identify five stages of this process, five stages of academic ethics management evolution, each representing the preferred strategy of universities to think about the management of their ethical lives, starting with the total ignorance of this dimension and going as far as that in which it is fully integrated into all academic activities.

1. The first stage of ethics management in the university environment is the state of immorality ( the immoral), the total ignorance of the ethical dimension of a university's life. At this stage, universities are usually immoral and believe ethics is something that does not concern them. All these "immoral" universities are at a precarious level of integrating ethical values. Their ethics management strategy in the academic environment is a primitive utilitarian, requiring the making of decisions that are of benefit to as many students as possible (to maximize good) regardless of the means used. Such a rudimentary model of pseudo-management of ethics in academia has its own risks. History has shown that at some point the financial consequences of immorality can become fatal. Once the student has lost confidence in his academic institution providing educational services, it is virtually impossible to regain it. Then there may be a rupture between the moral culture of the university and the ethical preferences of a part of the students which may generate their migration or their staying in a state of dissatisfaction. However, this latent dissatisfaction may explode on the first public scandal. After that, it will produce the collapse of the university. The risk of scandal in "immoral" universities is extremely high. Relationships with deceived students can also gradually deteriorate to a level where they are irreparable, causing university collapse. 


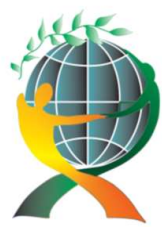

\author{
(online) $=$ ISSN $2285-3642$ \\ ISSN-L = $2285-3642$ \\ Journal of Economic Development, Environment and People \\ Volume 7, Issue 4, 2018 \\ URL: http://jedep.spiruharet.ro \\ e-mail: office jedep@spiruharet.ro
}

2. A higher stage of ethics management in the academic environment is the reactive academic stage. At this stage, university management (rector, vice-rectors, university senate, deans or department managers) realizes that something must be done to avoid the risk of unethical behavior. For them, these risks are real. Nevertheless, their ethical competence is very absent. Such universities are convinced that a display of moral commitment (the presence of a set of moral values) will create an appropriate context for ethical behavior at the academic level. These universities claim to be ethical without ensuring their management's compliance with the set of ethical standards. They have formally adopted ethical codes, but do nothing with them. This is in fact a proof of incapacity to do ethics management in the university environment, and therefore immoral behaviors prevail in these institutions. However, such behaviors are usually unpunished because there is no culture of evil represented by them. Universities at this stage are apparently sensitive to threats from unethical behaviors and formulate to them behavioral standards and moral codes. Like the immoral universities, those in the reactive state are very susceptible to scandal - easy to trigger as long as there is a big gap between ethical standards and real behavior. Formal gestures do not convince the teachers or the students, and the lack of confidence can thus advance to fatal levels ("I do not want to learn in Romanian universities", "I do not want to follow a master program in Romania"). Because the mere existence of codes does not guarantee moral behavior, what would otherwise be required is a more proactive managerial attitude, an effective ethical commitment to universities.

3. The ethical academic compliance standard satisfies this requirement for effective ethical commitment to universities. The third stage in the evolution of ethics management in academia means consciously engaging universities in monitoring and managing their ethical performance. Instead of having an academic code of ethics in order to reassure students and teachers, the code becomes the standard in which the university measures its own ethical performance. The Code is applied through disciplinary measures and penalties that are being pursued by the administration. Management's aim here is to prevent unethical behavior and eliminate costs associated with it, i.e. behaviors that affect the reputation of the university, such as scandals, poor quality of educational services provided or fraud. It is known that a good ethic reputation attracts students who have become more and more attentive to ethical details. Ethically compliant universities are explicitly committed to regulating academic ethics and eradicating unethical behavior. They periodically review their ethical code to adapt it to the circumstances. To be effective, the establishment of a managerial function to guide its compliance process must accompany this code. An "office of ethics" or compliance office (ethics desk) can ensure this. The managerial process of ethics in academia can be even more complex and include ethical auditing and regular public reporting of the university's ethical performance. The disadvantage of the compliance strategy is that the ethical standards of the university are imposed from the outside, which diminishes the moral autonomy and responsibility of the teaching staff. This type of management poses the risk of bureaucratization, artificially multiplying the rules, and obsession with imposing them through penalties. That is how we find in such ethical codes a substantial chapter of administrative, even penal sanctions, and the functions of the ethics committees are reduced to one: the resolution of disputes.

4. The stage of ethical academic integrity is the one that assures an internalization of ethical values and standards in the academic environment. Instead of pursuing their imposition from the outside, the subjective commitment of staff is pursued in relation to a multitude of values that are specific to the educational institution and define it (academic ethics "integrity"). Along with this, it enters the special field 


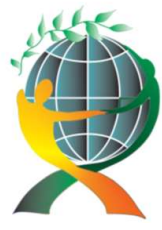

\author{
(online) $=$ ISSN $2285-3642$ \\ ISSN-L = $2285-3642$ \\ Journal of Economic Development, Environment and People \\ Volume 7, Issue 4, 2018 \\ URL: http://jedep.spiruharet.ro \\ e-mail: office jedep@spiruharet.ro
}

- which requires a special managerial competence - of "value training and value engagement" in a university. Its goal is not only profit, but also raising the level of ethical academic performance, but not by penalizing unethical academic behavior, but by encouraging ethical academic behavior. Universities engage on this path when they realize that ethical academic performance is of strategic importance and is a favourable factor in the competition on the university market. The managerial strategy specific to this stage is one that facilitates the internalization of ethical academic standards to all members of academic life. Such a strategy starts with a comprehensive diagnosis of the ethical culture of the university. It promotes the discussion of the ethical aspects of university life, and believes that the model offered by moral academic leaders is decisive. The training of staff capable of making informed ethical decisions - their training on ethical academic decision-making methods - as well as the emphasis on reward rather than penalty is also characteristics of universities in this stage of development. Internalizing values has the effect that teachers have the task and the ability to do ethics management in each of their academic backgrounds.

5. In time, there is a profound transformation in academic culture - an "ethics management in the transformational academic environment". The stage of total alignment is characterized by the integration of ethics into the purpose, mission and goals of the university. Ethics is no longer seen as one of the aspects of academic life that must also be led, but it is an integral part of the university without which it cannot fulfill its purpose and mission. Ethical academic thought is considered to be of strategic importance, and unethical academic behavior is seen not only as a threat to the success of the university, but also as a very rationale of being the institution subvert. The goal of ethics management in the university environment is to strengthen academic morals as an essential part of the university's culture and purpose. The University will also create a specific managerial position (a director with ethical issues) and an ethics committee, but its specificity is that all university management must play a role in this process, and this means that it must integrate ethics into the structure of their own academic management. Managerial accountability for university ethics is no longer limited to a special ethical function (an office), but dispersed throughout the university and at all its managerial levels (rector, dean, departmental directors). Such a university will not focus on punishing unethical academic behaviors, nor on rewarding ethical ones, but on celebrating those who become personalities of academic life and who embodies the vision, purpose and moral commitments of the university. Ethical commitment becomes a second nature of its members.

\title{
3. The academic Romanian learning system as a state of fact
}

The description of Rossouw and van Vuuren's five stages of evolution of ethics management can be a useful tool in raising awareness of the differences between ethics management in universities across universities, helping to sketch the direction of its evolution.

As a conclusion, we can say that there is an ethical code in all Romanian universities because they all responded to an order of the minister of education. Therefore, the ethical codes were not created to meet a need, but a requirement. However, the codes are made in most cases by colleagues in the academic world and not by some people specializing in management, which is why their amateur character is often flagrant. Professional academic managers who exist in English and American universities, etc. are trained through a specific training and have extensive knowledge of how to make a university budget, how to make 


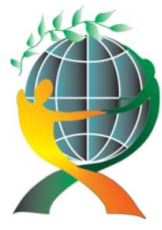

\author{
(online) $=$ ISSN $2285-3642$ \\ ISSN-L = $2285-3642$ \\ Journal of Economic Development, Environment and People \\ Volume 7, Issue 4, 2018 \\ URL: http://jedep.spiruharet.ro \\ e-mail: office jedep@spiruharet.ro
}

a strategic plan, how to ensure quality in the university, etc. The difference is in the hard reality of interuniversity competition, and this difference is enormous.

In this context, we obviously ask ourselves whether there have been instruments and tools for the application of these codes. To this question, the answer is rather negative. In addition, that's why. Codes can be put into operation and developed by Ethics Committees where there are experts in ethical decisionmaking methods. Committees exist in all universities, but unfortunately, most are focused exclusively on litigation, not on the application or development of the code of ethics. For example, ethical training - even compliance - is such a means of implementation. At the academic level, many universities say that there is an ethical training with teachers, but often teachers say they have been personally involved in such an activity, but they are done all in a hurry. The dedicated phone line, designed to provide feedback from the organization's staff, does not exist in the vast majority of universities, although it is desirable. At the end of it there should be moral consultants and consultancy activities, but they do not exist and the attitude towards their usefulness is rather reserved. Ethical audit activities were rarely conducted in the Romanian academic environment. Or if they are made, they often appear only in documentation. The inclusion of ethical academic restrictions in the strategic plan is rather absent, as the strategic plan is rather formal. Also, in our country, ethical debates around ethical issues of the university are not encouraged. At the same time, ethical criteria are not part of the promotion grid. The majority impression is that there is an ethical organizational culture, but lack of ethical training, moral complaints, ethical discussion, or ethics insertion into university management makes this answer problematic. One good thing is that a plurality of ethical visions, not just the Christian one, is becoming aware and accepted. So there are formal codes and ethical committees, but the means to implement moral norms are extremely fragile.

It could be argued that moral issues are considered as important for universities, since we believe that compliance with ethical standards is in the benefit of the educational institution and that the university has moral obligations to young people who appeal to it. At the same time, ethical criteria for hiring are spontaneously used (references from the university where the teacher had been previously employed). It is also to be recognized that there are still, occasionally, significant moral problems in universities (giving and taking bribes to exams, sexual harassment, plagiarism, etc.), and that often immoral behaviors are often claimed, that both teachers and administrative staff (secretaries, cashier, technical-sound service, service staff) can still be educated morally. We believe there is an organizational culture conducive to ethics, although there is no exercise in the debate on ethical issues in academia.

\title{
4. Conclusion:
}

We consider some examples of priority ethical themes for Romanian universities, so for the ethical training, which can take place there. Here is the examples: living and taking bribe at exams; sexual harassment; private use or appropriation of goods from the university's patrimony; drinking alcohol during the program; plagiarism; conflict of interest; influence traffic (promotions etc.); verbal aggressiveness in some professors and students; arrogant treatment of students; nepotism in employment and students' grades; misogynism; violation of the right to confidentiality; student stigmatization to provide material advantages.

Romanian universities seem to be between the reactive and the compliance levels. The development of critical, autonomous moral thinking or the assimilation of ethical decision-making methods are not explicit 


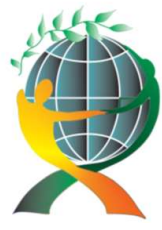

\author{
(online) $=$ ISSN $2285-3642$ \\ ISSN-L = 2285 - 3642 \\ Journal of Economic Development, Environment and People \\ Volume 7, Issue 4, 2018
}

URL: http://jedep.spiruharet.ro

e-mail: office jedep@spiruharet.ro

goals, and there is neither the exercise of public moral debates nor the integration of moral criteria into university management. In conclusion, Romanian universities are in the best case at the level of compliance, with variations from one university to another. It is a more declarative stage of ethical evolution, in which was made a first ethical code exercises, generally, having an educational function, and it is not mandatory. However, the general attitude is favorable to recognizing the existence of moral issues in universities, its importance and complexity, which requires skilled people, although there are great reservations about accepting specialists dedicated to this issue or "moral counselors". "Collegial" style also seems to be preferred in solving this problem.

\title{
5. References
}

[1] Adams, Scott Raymond. The Dilbert Principle. How to Fail at Almost Everything and Still Win Big. Kind of the Story of My Life, Penguin Books Limited, New York, USA, 2013.

[2] Adkinson, S. J., Mulvihill, T. M. Examining Organizational Culture and Subculture in Higher Education: Using the Competitive Values Framework and the Three-Perspective Theory, Doctoral Thesis, Ball State University, Dept. of Educational Studies - Theses (D. Ed.), 2005.

[3] Altbach, P. G., Teichler, U. Internationalization and Exchanges in a Global University, Journal of Studies in International Education, Vol. 5, No 1, 2001, pp. 5-25.

[4] Andrei, T., Lefter, V., Oancea, B., Stancu, S. A comparative study of some features of higher education in Romania, Bulgaria and Hungary, Romanian Journal of Economic Forecasting, Vol. 13, Issue 2, 2010, pp. 280-294.

[5] Angell, Robert J., Heffernan, Troy W., Megicks, Phil. Service quality in postgraduate education, Quality Assurance in Education, Vol. 16, No. 3, 2008, pp. 236-254.

[6] Standardization Association from Romania. SR EN ISO 9004: 2010 - Leading an organization to a sustainable success. An approach from the perspective of quality management, Publishing House of Standardization, Bucharest, 2010.

[7] Barnett, R. The idea of quality. Voicing the educational, in DOHERTY, G. (ed.), Developing quality systems in education, Routledge, London \& New York, 2005.

[8] Bowers, H. F. Designing quality course management systems that foster intraprofessional education. Nurse Education Today, 26, 2006, pp. 726-731.

[9] Bratianu, C., Lefter, V. (). University Strategic Management, Rao Publishing House, Bucharest, 2001, pp. 82-94.

[10] Brochado, Ana. Comparing Alternative Instruments to Measure Quality of Service in Higher Education, Quality Assurance in Education, Vol. 17, No. 2, 2009, pp. 174-190.

[11] Bryson, M. J. Strategic Planning for Public and Nonprofit Organizations, Arc Publishing House, Bucharest, 2002.

[12] CIHE, SRHE, CCC, IBE. Managing Ethical Issues in Higher Education, The Council for Industry and Higher Education, Institute of Business Ethics, Society for Research in Higher Education, Council of Church Colleges, ISBN 1874223 51 3, CIHE and Brunel University, London, UK, 2016.

[13] Constantinescu, M. Ethics Management and Social Responsibility: Complementary or Disjunctive Organizational Practices?, CCEA - https://www.ccea.ro/management-eticii-and-responsabilitate-social-practici-organizarecomplementare-sau-disjunctive, 2010.

[14] Crane, A. Business Ethics: Managing Corporate Citizenship and Sustainability in the Age of Globalization, Oxford University Press, 3rd Edition, UK, 2016.

[15] Christmas, D., Morar, V., Macoviciuc, V. (ed.). Ethics of Business, Paideia Publishing House, 2005.

[16] Dill, D. Quality Assurance in Higher Education: Practices and Issues in B. McGaw, E. Baker \& P. Peterson (Editorsin-Chief): The 3rd International Encyclopedia of Education, Elsevier Publications, 2007.

[17] Donaldson, T., Gini, A. R. (eds.). Case Studies in Business Ethics, Prentice Hall Publisher, New York, USA, 1990.

[18] Elkin, G., Devjee, F., Farnsworth, J. Visualization of the Internationalization of Universities, Vol. 9, Issue 4, June, 2005, pp. 318-329. 


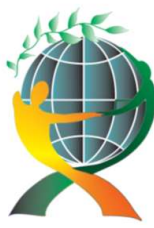

\author{
(online) $=$ ISSN $2285-3642$ \\ ISSN-L = $2285-3642$ \\ Journal of Economic Development, Environment and People \\ Volume 7, Issue 4, 2018
}

URL: $\underline{\text { http://jedep.spiruharet.ro }}$

e-mail: office jedep@spiruharet.ro

[19] Freeman, C. Strategic Management: A Stakeholder Approach, Pittman, New York, 1984.

[20] Fullan, M. The New Meaning of Educational Change (Fourth Edition), Teachers College, Columbia University, New York and London, 2007.

[21] Gareth, Smith, Smith, Alison. Evaluating service quality in universities: a service part perspective, Quality Assurance in Education, Vol. 15, No. 3, 2007, pp. 334-351.

[22] Gavreliuc, A. Intercultural Approach of Organizations - a Romanian Perspective in E. Avram \& C. L. Cooper (eds.), Organizational-Managerial Psychology. Current Trends, Polirom, lasi, 2009, pp. 222-247.

[23] Gavril, T., Lefter, V. Organization Management, Economic Publishing House, Bucharest, 2007.

[24] Gherasim, Zenovic (coord.), Andronie, M., Avram, L., Ghirghita, E., Gurgu, E, latagan, M., Ionescu, L., Mihalcioiu, R. Ethics and Academic Integrity, Romania Publishing House of Tomorrow, Bucharest, 2019.

[25] Glover, J. The Domain and Limits of Moral Argumentation in V. Muresan (ed.), Moral Philosophy of R. M. Hare, Paideia Publishing House, Bucharest, 2006.

[26] Gribincea, A. Ethics, Social Responsibility, and Corruption as Risk Factors, Annals of Spiru Haret University. Economic Series, Vol. 17, Nr. 1, Romania Foundation of Maine Publishing House, Bucharest, 2017, pp. 21-33.

[27] Gurgu, Elena. Ethics in Business, Romanian Tomorrow Foundation, Bucharest, 2018.

[28] Hardy, D. E. Ethical Considerations Affecting Teaching in Community Colleges: An Abundance of Feelings and Limited Facts. Community College Journal of Research and Practice, 26: 5, 2010, pp. 383-399.

[29] Hare, R. M. Essays on the moral concepts. New studies on practical philosophy, University of California Press, Berkeley and Los Angeles, USA, 1972.

[30] Hartley, R. Business Ethics: Mistakes and Successes, Willey, USA, 2005.

[31] HEFCE. Strategic Planning in Higher Education - a guide for heads of institutions, senior managers and members of the governing bodies, 2000. (Http://www.hefce.ac.uk/pubs/hefce/2000/00_24.htm)

[32] Hosmer, L. T. The Ethics of Management. A Multidisciplinary Approach, 7th Edition, McGraw-Hill Education, New York, USA, 2011, https://www.ucc.ie/en/media/academic/appliedpsychology/ethicsforms/Briefingonlnformed ConsentforResearchers.pdf

[33] Hussey, T., Smith, P. The Trouble with Higher Education. A Critical Examination of our Universities, Taylor \& Francis e-Library, 2010.

[34] Jeurissen, R. Moral complexity in organizations, in M. Korthals, R. Bogers (eds.), Ethics for Life Scientists, Springer, 2005.

[35] John Wiley \& Sons Weiss, J. W. Business Ethics: A Stakeholder and Issues Management Approach (5th ed.), Cengage Learning, 2009.

[36] Kant, Immanuel. Critique of Practical Reason, Univers Enciclopedic Gold Publishing House, Bucharest, 2010.

[37] Kaptein, M. Ethics Management: Auditing and Development of the Ethical Content of Organizations (p. 42). Dordrecht, Netherlands: Kluver Academic Publishers, 1998.

[38] Kaptein, M. Business Codes of Multinational Firms: What Do They Say?, Journal of Business Ethics, no. 50, 2004.

[39] Kim, Y. A. Common Framework for Ethics of the 21st Century, UNESCO, Paris, MacDonald, C. Guidance for Writing a Code of Ethics (chrismac@ethicsweb.ca), 1999.

[40] LeClair, D., L. Ferrell. Innovation in Experiential Business Ethics Training, Journal of Business Ethics, 23, 2000.

[41] Lefter, V., Bogdan, A. Academic Management of International Relations, Management \& Marketing Magazine, ASE, Bucharest, 2007, pp. 79-86.

[42] Lefter, V., Bratianu, C., Agapie, A., Agoston, S., Orzea, I. Intergenerational knowledge transfer in the academic environment of knowledge-based economy, Amfiteatru Economic Journal, Bucharest: The University of Economics, vol. 13, Issue 30, 2011, pp. 392-403.

[43] Macdonald, R., Wisdom, J. Academic and Educational Development - Research, Evaluation, and Change Practice in Higher Education, Taylor \& Francis e-Library, 2004.

[44] McNamara Carter. Complete Guide to Ethics Management: An Ethics Toolkit for Managers, 2002, http://www.managementhelp.org/ethics/ethxgde.htm on the Web. 


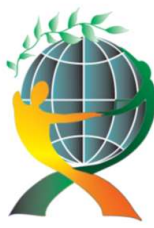

\author{
(online) $=$ ISSN $2285-3642$ \\ ISSN-L = $2285-3642$ \\ Journal of Economic Development, Environment and People \\ Volume 7, Issue 4, 2018
}

URL: http://jedep.spiruharet.ro

e-mail: office jedep@spiruharet.ro

[45] Melé, D. Management Ethics: Placing Ethics at the Core of Good Management. London, UK: Palgrave Macmillan, 2012.

[46] Mellat-Parast, M., Digman, L. A. Learning: The interface of quality management and strategic alliances. Int. J. Production Economics, 114, 2008, pp. 820-829.

[47] Menzel, D. Ethics Management for Public Administrators, Sharpe, London, 2007.

[48] Mill, John Stuart. On liberty: With Mill's Essays on Utilitarianism \& Socialism, Independent Publishing Platform, London, UK, 2013.

[49] Miroiu, A. (ed.). Ethics Applied, Alternative Publishing House, Bucharest, 1995.

[50] Molina, L., Llore'Ns-Montes, J., Ruiz-Moren, A. Relationship between Quality Management Practices and Knowledge Transfer. Journal of Operations Management, 25, 2006, pp. 682-701.

[51] Mungiu-Pippidi, A. Civil Society and Control of Corruption: Assessing the Governance of Romanian Public Universities. International Journal of Educational Development, 2011. www.transparency.org/gcb2013/country/ ?country=romania

[52] Muresan, V. Management of Ethics in Organizations, University of Bucharest Publishing House, 2009.

[53] Muresan, V. Ethical Management Situation in Romania, 2009, EAA - https://www.ccea.ro/situatiamanagementului-etic-in-romania

[54] Narvaez, D. Does Reading Moral Stories Build Character?, Educational Psychology Review, vol. 14, no. 2, 2002.

[55] Neese, B. Managing Ethics in the Workplace, 2017, https://online.alvernia.edu/ethics-in-the-workplace

[56] Nguyen, Steve. Leadership Development, 2014, https://www.stevenguyenphd.net/leadership-development

[57] Nica, P., Nestian, A. Possibilities to orientate the organizational culture of a university in the spirit of total quality management, Project "University Community for Quality Management in Higher Education", Iaşi, 2011.

[58] Minister's Order no. 4.492 of 6 July 2005 on the Promotion of Professional Ethics in Universities, Issuer: Ministry of Education and Research of Romania, published in: Official Gazette of Romania no. 595 of July 11, 2005.

[59] Olaru, S. D., Gurgu, E. Ethics and integrity in multinational companies, The Review of International Comparative Management, The Bucharest Academy of Economic Studies, The Elitist Society of Management from Romania, Excellence Romanian Center for Comparative Management Studies, Vol. 10, Nr. 1, Bucharest, 2009, p. 113-120.

[60] Panaite, N. University Community for Quality Management in Higher Education. Handbook of Good Practice, West University of Timisoara, 2013.

[61] Papadima, L., Avram, A., Berlic, C., Murgulescu, B., Murgulescu, M.L., Popescu, M., Rughiniş, C., Sandu, D., Socaciu, E., Şercan, E., Ştefănescu, B., Tănăsescu, S.E., Voinea, S. Academic Deontology. Framework curriculum, University of Bucharest Publishing House, 2017.

[62] Puiu, S., Ogarca, R. F. Ethics Management in Higher Education System of Romania, Processia Economics and Finance, Vol. 23, 2015, pp. 599-603.

[63] Raicu, V. Local Ethics Committees in Romania, Romanian Journal of Bioethics, no. 3, 2007.

[64] Roland, K. Yeo. Brewing service quality in higher education. Characteristics of ingredients that make up the recipe, Quality Assurance in Education, Vol. 16, No. 3, 2008, pp. 266-286.

[65] Rossouw, G. J. van Vuuren, L. J. Modes of Managing Morality: A Descriptive Model of Strategies for Managing Ethics, Journal of Business Ethics, 46, 2003, pp. 389-402.

[66] Sallis, E. Total Quality Management in Education, Taylor \& Francis, London \& New York, 2005.

[67] Schmidt, H. W., Finnigan, J. P. TQ Manager: A Practical Guide to Managing a Total Quality Organization, Jessey Bass Publisher, New York, USA, 1993.

[68] Schwartz, M. Universal Moral Values for Corporate Codes of Ethics, Journal of Business Ethics, 59, 2005, p. 30.

[69] Shattock, M. Managing successful universities, Open University Press, 2003.

[70] Singer P. On Ethics, V. Muresan (ed.), Moral Philosophy of R. M. Hare, Paideia Publishing House, Bucharest, 2006.

[71] Smart, J. C. \& ST. John, E. P. Organizational Culture and Effectiveness in Higher Education: A Test of "Culture Type" and "Strong Culture" Hypotheses. Educational Evaluation and Policy Analysis, 16 (3), 1996, pp. 219-241. 


\author{
(online) $=$ ISSN $2285-3642$ \\ ISSN-L = $2285-3642$ \\ Journal of Economic Development, Environment and People \\ Volume 7, Issue 4, 2018 \\ URL: http://jedep.spiruharet.ro \\ e-mail: office jedep@spiruharet.ro
}

[72] Susanu, G. C. The postmodern ethics of global capitalism, Annals of Spiru Haret University. Economic Series, Vol. 11, Nr. 2, 2011, pp. 49-55.

[73] Stefan, Emilia Elena. Ethics and Academic Integrity, ProUniversitaria Publishing House, Bucharest, 2018.

[74] Taylor, J., Miroiu, A. Policy making, strategic planning and management of higher education, UNESCO, 2002.

[75] Thomas, E., Blair, M., Hughes-Hallet, T. \& Lampl, P. Increasing voluntary giving to higher education. Task force report to Government, 2004.

[76] Trevino, L. K., Weaver, G. Managing Ethics in Business Organizations, Stanford University Press, 2003.

[77] Trevino, L. K., Nelson, K. A. Managing Business Ethics (5th ed.), 2010.

[78] Tribus, M. Total Quality Management in Education. The theory and how to put it into work in Doherty, G. (Ed.), Developing Quality Systems in Education, Routledge, London \& New York, 2005.

[79] Wickramaratne Colton. My Adventure in Faith, Onward Books, Incorporated, New York and Los Angeles, USA, 2007. 